\title{
EFFECT OF Jerusalem artichoke AND Tigernut AS SUGAR SOURCES ON PATHOGENIC and PROBIOTIC BACTERIA GROWTH IN SOME FUNCTIONAL FOOD (BIO - YOGHURT AND WHEAT DOUGH)
}

EI - Reffaei, W. H. M.; A. F. Abdel - Salam; A. M.M. El-Kharamany and Eman M. Ragheeb Regional Center for Food and Feed (RCFF), Agric. Res. Center, Giza, Egypt.

\begin{abstract}
In recent time, there has been an increase interest to improve prebiotic material and probiotic bacteria mainly in food. This study aims to evaluate the effect of Jerusalem artichoke (JR) and Cyprus esculents (Tigernut or Chufa) (TN) as prebiotics source, to improve growth and survival of probiotic bacteria in yoghurt and as a preserved agent against the food borne bacteria in vitro. In addition, emphasis on improve nutritional value of dough using a new source of inulin by supplemented wheat flour with $J R$ and $T N$. In vitro JR and TN were used as prebiotic for evaluation their effect as growth promoters for prebiotic bacteria (Lactobacillus plantarum, Lactobacillus curvatus and Bacillus subtilis) and evaluated antimicrobial activity against Staphylococcus aureus at different concentrations (5.0 and 10.0\%). The results revealed that JR and TN contained of a sufficient amount of macronutrients carbohydrate, fiber and valuable amino acids. Sugar profile of these plants showed that, inulin was the most abundant polysaccharides in JR while TN was abundant in fructose. These polysaccharides (inulin and fructose) as considered as bioactive ingredients and prebiotic compounds. In addition, $10 \%$ supplementation level of JR or TN resulted in greater growth rates of prebiotic bacteria, as well as showed stronger antimicrobial activity. Therefore, these results could suggest a preferential utilization of $J R$ and $T N$ in the people diet for improving the nutritional value and provide health benefits as functional foods, as well as considered economic and natural antimicrobial agent in food preservation.
\end{abstract}

Keywords:Jerusalem artichoke, Tigernut, Inulin, Yoghourt, Wheat dough, Prebiotic Antimicrobial,

\section{INTRODUCTION}

Probiotic foods including dairy products defined as food containing live microorganisms, which believed to enhance health by improving the balance of microflora in the jut (Tamime et al. 2005). The microorganisms that most commonly used as probiotics belong to the heterogeneous group of lactic acid bacteria and the genius Bifidobacterium. Prebiotics are non-digestable components of functional food that stimulate the proliferation and activating of bacterial population desirable in the colon and inhibit pathogen multiplication, hence beneficially acting on the host (Mattila et al. 2002). The most important prebiotics are fructans (inulin and oligofructoses), glucans and mannans, which are soluble and fermentable fibers (Gibson et al. 2004). Supplementation of skim milk with inulin, even at a low concentration significantly improves the growth and viability of Lactobacillus acidophilus, Lactobacillus rhamnosus and Bifidobacterium lactis (Cruz et al. 2010 and Oliveria 2011). Inulin is among the most famous prebiotic compounds. Also 
when inulin added to the food in low concentrations the rheological properties and sensory quality of the product improve (Aguilar et al. 2015). Cyperus esulentus, root stock snack or earth almond is among the popular, cheap and sweet convenience foods in Africa. It has been cultivated since the fourth millennium BC in Egypt, and for several centuries in Southern Europe. It is a perennial tuber commonly found in Egypt. The major components of this tuber are complex carbohydrates. It is comprise fructosyl-fructose linked compounds such as inulin. In human nutrition intervention trials, inulin appeared to be more effective than oligofructose in reducing triglyceridemia, whereas in animals (especially in rats), both products were equally active. In the high fat diet HF and the diets, containing inulin delayed the lowest plasma triglyceride and total cholesterol levels (Reimer and Russell 2008). In young adolescents, daily consumption of a combination of prebiotic short- and longchain inulin-type fructans significantly increases calcium absorption and enhances bone mineralization during pubertal growth. Effects of dietary factors on calcium absorption may be modulated by genetic factors, including specific vitamin D receptor gene polymorphisms (Abrams et al. 2005).

Among other plants rich inulins is Jerusalem artichoke (Helianthus tuberosus L.) (JR), its tuber accumulates similar levels of inulin (10-20\%) of fresh tuber). Therefore, this study aims to evaluate effect of JR and TN as prebiotics source in fermented dairy products and assess their antimicrobial effect. In addition, improve nutritional quality of bake product by new source of fructosan.

\section{MATERIALS AND METHODS}

Preparation of samples:

Jerusalem artichoke (JR) was kindly obtained from farm from Sharkia Egypt. Brown Cyperus esculents (tigernut tubers or Chufa) (TN) was bought from local market (Sharkia Egypt). TN they screened on a metallic sieve in order to calibrate them according to their average diameter (two sieve sizes were used 1 and $0.5 \mathrm{~cm}$ ), then washed with tap water to remove sands and other undesirable materials. Also Jerusalem artichoke was sliced cutting (think $0.5 \mathrm{~cm}$ ) and dried on oven drying at $50^{\circ} \mathrm{C}$ until dry, then ground into flour using attrition mill (Globe, China) and passed through a $0.45 \mathrm{~mm}$ mesh size sieve, packaged in an airtight polyethylene bag and stored in a plastic container with lid and then stored in a freezer at $-18^{\circ} \mathrm{C}$ until analysis.

\section{Soaking experiments:}

Soaking experiments on TN were conducting according to Turhan et al. (2002). Beakers $(500 \mathrm{ml})$ containing $400 \mathrm{ml}$ distilled water were placed in a constant temperature water bath at $25^{\circ} \mathrm{C}$. During soaking, tubers periodically removed, superficially dried with a tissue paper. The experiment was terminated when tuber moisture content attained an equilibrium value, i.e., when the increment change in sample weight was less than $0.01 \mathrm{~g}$. At least three experiments conducted for every tiger nut diameter at soaking temperature. After soaking TN was drained, rinsed, and ground into flour using attrition mill (Globe, China). The flour samples were passed through a $0.45 \mathrm{~mm}$ mesh size sieve. It was then packaged in an airtight polyethylene 
bag and stored in a plastic container with lid and then stored in a freezer at) $18^{\circ} \mathrm{C}$ from where samples were taken for analysis.

Chemical composition of JR and TN:

Fat, protein, ash, moisture and fiber contents were determined by AOAC (2012), while carbohydrates were obtained by difference.

Determination of amino acids (AA):

It performed according to method described in AOAC (2012). Samples were analyzed for AA using Amino Acid Analyzer (BIOCHROM 30, serial 103274, with EZ chrom manual 2004), software used for data collection and processing. The results performed by percentage of total crude protein. Determination of tryptophan carried out using method described by Miller (1967) after hydrolysis of samples with barium hydroxide.

The predicted protein efficiency ratio (P-PER) was calculated using the equation according to Alsmeyer et al. (1974): P-PER $=-0.468+0.454(\mathrm{Leu})$ -0.105 (Tyr)

Determination of fatty acids of plants and bio-yoghourts:

Samples of each were dried at $60^{\circ} \mathrm{C}$ and ground in a coffee grinder to a particle size of approximately $1 \mathrm{~mm}^{3}$. Fats were extracted from the samples with petroleum ether $\left(60-80^{\circ} \mathrm{C}\right.$ boiling fraction) in a Soxtec apparatus (FOSS Tecator, Auckland, NZ). Fatty acids in the extracted oils were esterified by $\mathrm{BF}_{3}$ and methanol into fatty acid methyl esters (FAMES) according to described method of AOAC (2012). The fatty acid methyl esters analyzed by gas liquid chromatography (Shimidazu GC 2010) using DB-wax column. The carrier gas was Helium with a flame ionization detector, fatty acids identified according to standard FAME.

\section{Determination of polysaccharides:}

Determination of polysaccharides in JR was done using the method of (Cabezas et al. 2002), 4 grams of sample were dissolved in HPLC grade water sonicated for one hour, centrifuged for $10 \mathrm{~min}$ at $4000 \mathrm{Xg}$, the supernatant were quantitive transferred to measuring flask $100 \mathrm{ml}$ and completed to the mark HPLC grade water sonicated again for $15 \mathrm{~min}$, then poured through $0.20 \mu \mathrm{m}$ membrane filter. While in $\mathrm{TN}$, using described method by Mano et al. (2009) and Helle et al. (2010), was used $1 \mathrm{~g}$ of sample were dissolved in HPLC grade water sonicated for one hour, centrifuged for $10 \mathrm{~min}$ at $4000 \mathrm{Xg}$ the supernatant were quantitate transferred to measuring flask $100 \mathrm{ml}$ and completed to the mark HPLC grade water sonicated again for $15 \mathrm{~min}$. Poured through $0.20 \mu \mathrm{m}$ membrane filter completed to volume with acetonitrile. Chromatographic analysis of the sugars in JA and TN were determined by HPLC, fitted with RI detector, column typr Rezex $300 \times 7.8 \mathrm{~mm}$, at $80^{\circ} \mathrm{C}$, flow rate $0.6 \mathrm{ml} / \mathrm{min}$ with water $100 \%$ as mobile phase according to Javier et al. (2011).

\section{Determination of vitamins:}

Vitamin B1 (thiamine), B2 (riboflavin) were measured as described by Bognar (1992), Beckman HPLC , injector and data handling item PerkinElmer flourencece detector LC240 and C18 column $25 \mathrm{~cm} \times 4.6 \mathrm{~mm}$ were used. Vitamin E (a-tocopherol) was measure by using HPLC according to AOAC (2012), determination was done by using isopropanol $n$-heptane, 
Spectrophotometer detection at $285 \mathrm{~nm}$. Vitamin C was assessed according to the method of Campos et al. (2009), briefly homogenized samples (about $1 \mathrm{~g}$ ) were added to $15 \mathrm{ml}$ of extraction solution (3\% metaphosphoric acid, $8 \%$ acetic acid, $0.3 \mathrm{~N}$ sulfuric acid and $1 \mathrm{~m} \mathrm{M} \mathrm{EDTA).} \mathrm{After} \mathrm{filtrate} \mathrm{under} \mathrm{vacuum,}$ it diluted in ultrapure water and adjusts the volume to $25 \mathrm{ml}$, then centrifuged at $1789 \mathrm{~g}$ for $15 \mathrm{~min}$. The supernatant was stored in a refrigerator at $5^{\circ} \mathrm{C}$ and analysis by using HPLC.

\section{Determination of minerals:}

Mineral contents in JR and TN identified as described by AOAC (2012). The minerals were determined by digesting $0.5 \mathrm{~g}$ sample in concentrated $\mathrm{HNO} 3$ at a temperature of $85^{\circ} \mathrm{C}$ and then in $\mathrm{HClO} 4$ at temperature of $180{ }^{\circ} \mathrm{C}$ until $1-2 \mathrm{ml}$ of digested samples left. The digested samples then filtered and volume made up to $25 \mathrm{~mL}$. These samples run through an Atomic Absorption Spectrophotometer (Varian, AA240, and Victoria, Australia) using air acetylene flame to determine the minerals content.

\section{Extraction and identification of compounds by GC-MS in methanol} extract:

The GC-MS instrument used to separate and detect methanol extracting JA and TN according to the method described by Boskou (2005) and AOAC (2012). One gram of flour was extracted three times with methanol $12 \mathrm{ml}$. The extracted combined and methanol evaporated under reduced pressure. The residue was dissolved in acetonitrile $(2 \mathrm{ml})$ and washed two times with hexane $(3 \mathrm{ml})$. Acetonitrile evaporated under vacuum and the residue dissolved in methanol $(1 \mathrm{ml})$. Injections of $10 \mu \mathrm{l}$ from this dissolve-extracted lipid in methanol were performed using a GC/MS (Agilent Technologies $6890 \mathrm{~N}$ computerized system coupled to an MSD, Agilent 5973B mass spectrometer).

Preparation of bio-yoghurt:

The bio-yogurt samples were made from cow milk and prepared as described by Shori and Baba (2011). Samples divided into five groups (100 $\mathrm{ml}$ milk /each), JR and TN flours added at $10 \%$. Each of five groups mixtures placed in a glass jars and heated at $85^{\circ} \mathrm{C}$ for $30 \mathrm{~min}$, then allowed to cool $(40$ - $42{ }^{\circ} \mathrm{C}$ ) subsequently inoculated with Lactobacillus plantarum and Lactobacillus curvatus bacterial cultures at $40^{\circ} \mathrm{C}$ and fermented until pH 5.7. After incubation, yoghurts were stored in $4^{\circ} \mathrm{C}$ and examined in order to check the growth of lactic acid bacteria.

Texture profile analysis (TPA):

It was determined by a universal testing machine (Cometech, Btype, Taiwan) provided with software. An Aluminum $25 \mathrm{~mm}$ diameter cylindrical probe was used in a TPA double compression test to penetrate to $50 \%$ depth, at $1 \mathrm{~mm} / \mathrm{s}$ speed test. Hardness (N), gumminess, chewiness, adhesiveness, cohesiveness and springiness calculated from the TPA graphic. Firmness $(\mathrm{N})$; maximum force required to compress the sample (was determined as the maximum penetration and expressed in yoghurt), Cohesiveness; extent to which sample could be deformed prior to rupture, Springiness; ability of sample to recover to its original shape after the deforming force was removed, Gumminess; force to disintegrate a yoghurt sample for swallowing (hardness $\times$ Cohesiveness) and Chewiness; work to masticate the sample for 
swallowing (springiness $\times$ gumminess) were determined as described by Bourne (2002).

Organoleptic properties:

Organoleptic properties of bio-yogurt was running after 1 day of refrigerated storage. Ten untrained panels' participants selected randomly for sensory evaluation. Each panel tested two types of bio-yogurt one fortified yogurt with biofidobacterium and JR and second fortified yogurt with biofedobacterium and TN. The evaluation was scored on 1-10 point hedonic scale $(1-2=$ extremely poor, $3-4=$ poor, $5-6=$ fair, $7-8=$ good, $9-10=$ excellent) according to taste sour, bitter, sweet, aroma and overall acceptability.

Rheological properties of dough by Alveograph:

White wheat flour used as control (72\% extraction ratio), JR and TN /wheat flour blends were prepared at $5 \%, 10 \%$ and $15 \%$ of white wheat flour substitutions and wheat. Rheological properties are maintained by Alveograph to determine the quality of wheat flour blends with JR and TN according to AACC (2000) method No (AACC 54-30A). Each Alveograph result was analyzed for the following parameters: Tenacity $(P) \mathrm{mm} \mathrm{H}_{2} \mathrm{O}$ : the maximum over pressure needed to blow the dough bubble, expresses dough resistance; Extensibility $(L) \mathrm{mm}$ : the length of the curve, expresses dough extensibility, Configuration rate $(P / L) \%$ : the configuration ratio of the Alveograph curve, Index of swelling $(G)$ : index of swelling, Baking strength or (deformation energy (W)10E-4 J: baking strength (surface area of the curve), Elasticity index (le) \%: elasticity index.

\section{Microbiological evaluation:}

\section{Bacterial strains:}

Each Lactobacillus plantarum code no . (ATCC14917) and Lactobacillus curvatus code no. (1136T) strains were obtained from Microbiological Resources Center (Cairo MIRCEN), faculty of Agriculture, Ain Shams University. Staphylococcus aureus code no (A.F 15) and Bacillus subtilis strains were kindly provided by $\mathrm{Dr}$. Ahmed F. Abdel Salam, Regional Center for Food and Feed, Agriculture Research center, Giza, Egypt).

Isolates maintaining:

Each $L$. plantarum and L. curvatus isolates were maintained through monthly transfer on MRS agar, while Staph aureus and Bacillus subtilis (B. subtilis) isolates were maintained through monthly transfer on nutrient agar. All strains were stored at $4{ }^{\circ} \mathrm{C}$.

\section{Standard inoculants:}

Standard inoculants were prepared by inoculation of conical flasks (100 ml in volume containing $50 \mathrm{ml}$ of MRS broth $\mathrm{pH} 5.7$ ) for 24 at $30^{\circ} \mathrm{C}$ with loop of $L$. plantarum or $L$. curvatus isolates and another flask containing $50 \mathrm{ml}$ of nutrient broth $(\mathrm{pH} 6.8)$ for $24 \mathrm{hr}$ at $30{ }^{\circ} \mathrm{C}$ with a loop of Bacillus subtilis, beside flask containing $50 \mathrm{ml}$ of buffered peptone water (pH 7.2) for $24 \mathrm{hr}$ at $37^{\circ} \mathrm{C}$ with loop of Staph aureus. Achieve viable cells count were determined by serial dilution and subsequent enumeration on MRS agar for $L$. plantarum and L. curvatus, nutrient agar for Bacillus subtilis and Vojel Johnson agar for Staph aureus. Plant substances of JR and TN were prepared at different 
concentrations (5.0 and $10.0 \%$ ) and tested as growth promoter for $L$. plantarum and $L$. curvatus activity against Staph aureus.

Effect of JR and TN on probiotic bacteria strains in vitro:

Erlenmeyer flasks $(250 \mathrm{ml})$ contained $50 \mathrm{ml}$ of MRS broth were inoculated with $1 \mathrm{ml}$ of $L$. plantarum or $L$. curvatus inoculum containing about $10^{13} \mathrm{cfu} / \mathrm{ml}$, then different concentrations (5.0 and $10.0 \%$ ) of JR or TN were added to the flask separately, which incubated at $30^{\circ} \mathrm{C}$ for $24 \mathrm{hr}$ on rotary shaker (100 rpm). Moreover, flasks contained $50 \mathrm{ml}$ of nutrient broth $(\mathrm{pH} 6.8)$ were inoculated with $1 \mathrm{ml}$ of Bacillus subtilis inoculum containing about $10^{11}$ $\mathrm{cfu} / \mathrm{ml}$ and flasks contained $50 \mathrm{ml}$ of brain heart infusion broth $(\mathrm{pH} 7.4)$ were inoculated with $1 \mathrm{ml}$ of Staph aureus inoculum containing about $10^{13} \mathrm{cfu} / \mathrm{ml}$ then added different concentrations (5.0 and $10.0 \%$ ) of JR or TN were added to the flask separately, which incubated at $30{ }^{\circ} \mathrm{C}$ for $24 \mathrm{hr}$ on rotary shaker (100 rpm). The control inoculated without any treatment for each bacterial strain at the same experimental condition.

Antimicrobial effect of JA or TN:

Yoghurt samples five treatments as follow control, second and third containing JR, fourth and fifth containing TN at 5.0 and $10.0 \%$ of, respectively. All samples inoculated with Staph aureus (about $10^{13} \mathrm{cfu} / \mathrm{ml}$ ) and inoculated at $37^{\circ} \mathrm{C}$ for $3 \mathrm{hr}$, then put at $4^{\circ} \mathrm{C}$, the mean cfu/ml for Staph aureus was determined according to (Berrang et al. 2001).

\section{RESULTS AND DISCUSSION}

\section{Chemical composition of JR and TN:}

The nutrients and proximate analysis of $\mathrm{JR}$ and $\mathrm{TN}$ are presented in (Table 1). Results revealed that, JR and TN contained carbohydrate 78.00 and $41.22 \%$, crude fat 0.38 and $35.43 \%$, ash 5.22 and $4.25 \%$, fiber 1.33 and $5.64 \%$ and moisture 5.36 and $3.78 \%$, respectively. Codina-Torrella et al. (2014) reported that, the tigernut contain from 25.35 to $28.19 \%$ fat and 3.28 to $7.32 \%$ protein. The predominant constituent in JR carbohydrates was being $78.00 \%$ and follows by protein being $9.8 \%$. However, the carbohydrate and follows by crude fat, 41.22 and 35.43 , respectively, were the most predominate nutrients constituent in TN .

Table 1. Chemical comparison of Jerusalem artichoke (JR) and Tigernut (TN) /100 g dry base

\begin{tabular}{|l|c|c|c|c|c|}
\hline \multirow{2}{*}{ Nutrients } & \multirow{2}{*}{ RDV } & \multicolumn{2}{|c|}{ JR } & \multicolumn{2}{c|}{ TN } \\
\cline { 3 - 6 } & & Contents $^{* *}$ & \% of RDV & Contents ** $^{*}$ & \% of RDV \\
\hline Protein $(\mathrm{g})$ & 50 & $9.8 \pm 0.36$ & 19.6 & $9.7 \pm 0.16$ & 19.40 \\
\hline Fat $(\mathrm{g})$ & 65 & $0.38 \pm 0.22$ & 0.58 & $35.43 \pm 0.35$ & 54.51 \\
\hline Ash $(\mathrm{g})$ & - & $5.22 \pm 0.18$ & - & $4.25 \pm 0.44$ & - \\
\hline Fiber $(\mathrm{g})$ & 25 & $1.33 \pm 0.67$ & 5.32 & $5.64 \pm 0.15$ & 22.56 \\
\hline Moisture $(\mathrm{g})$ & - & $5.36 \pm 0.12$ & - & $3.78 \pm 0.65$ & - \\
\hline Carbohydrate $(\mathrm{g})$ & 300 & $78.00 \pm 0.31$ & 26.00 & $41.22 \pm 0.35$ & 13.74 \\
\hline
\end{tabular}

* RDV : Relative daily value; from the Food and Nutrition Board (2002) ;

** Values represent the mean $\pm S D$ of triplicate measurements 
Amino acids content in JR and TN:

Amino acids (AA) content in JR and TN are presented in Table (2). Results revealed that, the protein content of JR and TN containing total essential AA 19.89 and $14.33 \mathrm{~g} / 100 \mathrm{~g}$ protein, respectively, including methionine +cysteine, isoleucine, phenylalanine, threonine, valine and lysine with slightly differences between JR and TN. Data showed that, phenylalanine + tyrosine content was higher in JR than in TN. However, the overall quality of protein in the JR compromised by its high phenylalanine+ tyrosine content $6.13 \%$ of the total essential AA. Tryptophan was the least concentrated, in JR with values of $0.82 \mathrm{~g} / 100 \mathrm{~g}$ protein.

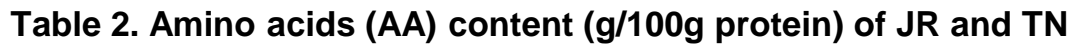

\begin{tabular}{|c|c|c|c|c|c|}
\hline \multirow{2}{*}{ AA composition } & \multirow{2}{*}{$\begin{array}{c}\text { WHO* ideal } \\
\text { AA( } g / 100) \\
\text { protein) }\end{array}$} & \multicolumn{2}{|c|}{ JR } & \multicolumn{2}{|c|}{ TN } \\
\hline & & AA & $\%$ WHO & AA & $\%$ WHO \\
\hline \multicolumn{6}{|c|}{ Essential AA } \\
\hline Isoleucine & 2.8 & 1.84 & 65.7 & 1.24 & 44.29 \\
\hline Leucine & 6.6 & 2.34 & 35.5 & 2.37 & 35.91 \\
\hline Lysine & 5.8 & 2.96 & 51.0 & 2.47 & 42.59 \\
\hline Methionine+Cysetine & 2.5 & 1.22 & 48.8 & 1.13 & 45.20 \\
\hline Phenylalanine+Tyrosine & 6.3 & 6.13 & 97.3 & 1.86 & 29.52 \\
\hline Phenylalnine & - & 2.13 & - & 0.99 & - \\
\hline Tyrosine & - & 4.00 & - & 0.87 & - \\
\hline Threonine & 3.4 & 2.24 & 65.9 & 1.86 & 54.71 \\
\hline Tryptophan & 1.1 & 0.82 & 74.5 & 1.24 & 112.73 \\
\hline Valine & 3.5 & 2.34 & 66.9 & 2.16 & 61.71 \\
\hline Total essential AA & 32.0 & 19.89 & 62.16 & 14.33 & 44.78 \\
\hline \multicolumn{6}{|c|}{ Non-essential AA } \\
\hline Aspartic & & 11.68 & & 13.12 & \\
\hline Glutamic & & 18.61 & & 17.50 & \\
\hline Serine & & 3.47 & & 5.83 & \\
\hline Proline & & 12.96 & & 5.47 & \\
\hline Glycine & & 4.01 & & 6.93 & \\
\hline Alanine & & 5.11 & & 8.02 & \\
\hline Histidine & & 3.10 & & 2.92 & \\
\hline Arginine & & 21.17 & & 25.88 & \\
\hline Total non-essential AA & & 80.11 & & 85.67 & \\
\hline P-PER & & 0.55 & & 0.52 & \\
\hline
\end{tabular}

P-PER: Predicted protein efficiency ratio. *WHO (1985) WHO/FAO Report.

However, JR contained the second predominant AA of lysine; leucine follows by valine as 2.16 , and similar ratio of leucine and valine $2.34 \mathrm{~g} / 100 \mathrm{~g}$ from total essential AA. In Table 2, TN contained an abundant AA ratio of lysine $(2.47 \mathrm{~g} / 100 \mathrm{~g})$, follows by leucine $(2.37 \mathrm{~g} / 100 \mathrm{~g})$ and valine $(2.16$ $\mathrm{g} / 100 \mathrm{~g}$ ). These results are lowering than obtained by Temple et al. (1989) who reported that chufa contain lysine $(4.9 \mathrm{~g} / \mathrm{g} / 100 \mathrm{~g}$ protein), leucine (2.9 $\mathrm{g} / 100 \mathrm{~g}$ protein) and valine $(2.5 \mathrm{~g} / 100 \mathrm{~g}$ protein). It is interesting to note that, the phenylalanine + tyrosine content of the JR was provide $97.3 \%$ of the 
WHO ideal protein standard. Proportion of tryptophan and follows by threonine and valine in JR provide 74.5 and about of $66.0 \%$ for the ideal standard protein of WHO. Total essential AA in TN (14.33 g/100g protein) which in lower than in JR $(19.89 \mathrm{~g} / 100 \mathrm{~g}$ protein). TN amino acid pattern provide about $11.3 \%$ of tryptophan was higher than WHO standard protein for children (Table 2). Compared to standard percentage amino acid in WHO profile, both of JR and TN were lacked in leucine and aromatic amino acids (phenylalanine+ tyrosine), respectively.

Concerning non-essential $A A$ content of $J R$ and $T N$ the results revealed that, the major abundant non-essential $A A$ in JR were arginine acid, glutamic acid, proline and aspartic with values 21.17, 18.61, 12.96 and 11.68 $\mathrm{g} / 100 \mathrm{~g}$ protein, respectively. TN contain high amount of arginine, which liberates insulin hormone and provides some digestive enzymes like catalase, lipase, and amylase, it could recommended for those who have problems with digestion, flatulence and diarrhea, also TN milk is a suitable drink for celiac patients and for the lactose-intolerant (Adejuyitan, 2011). Total non-essential AA for JA and TN accounted

80.11 and $85.67 \mathrm{~g} / 100 \mathrm{~g}$ protein, respectively. The Predicted Protein Efficiency Ratio (P-PER) is one of the quality parameters used for protein evaluation (FAO/WHO, 1991). The P-PER of JR and TN was 0.55 and 0.52 , respectively. This study showed that JR and TN nutritionally useful quantities of most of the essential amino acids and can serve as food supplements.

\section{Fatty acids composition in JR and TN:}

Fig 1. illustrated fatty acids composition of crude lipid fraction from JR and TN. The results revealed that, JR fatty acid profile is predominant in linoleic acid, c18:2n6 (55.34 \%) and follows by palmitic acid, C16:0 (29.04\%) and linolenic acid, C18:3n3 (9.6\%), these account more than $94 \%$ of total fatty acid. Oleic acid is the major fatty acid in TN ratio about $70 \%$ follows by palmitic acid, C16:0 and Linoleic acid, c18:2n6 (14.5\% and 8.8\%, respectively). Similar result by Muhammad et al. (2011) who found that, TN oil is predominantly consists of oleic acid with values ranging from 65.5 to $76.1 \%$. Dubois et al. (2007) reported that, the major fatty acids in TN oil are 14:0 (0.2\%), 18:0 (3.2\%), 20:0 (0.4\%), 16:1 n -7 (0.3\%), 18:1 n-9 (72.6\%), 18:2 $n-6(8.9 \%)$, and 18:3 n-3 (0.4\%). Moreover, TN oil has a monounsaturated profile ( $>60 \%$ monounsaturated fatty acids (MUFA)), similar to fatty acid profile of olive oil, hazelnut, macadamia nut, avocado, and apricot kernel oils (Dubois et al. 2007). Tigernuts reported as a helping agent in prevention heart attack and thrombosis by enhancing blood circulation, reducing low density lipoprotein (LDL-C) and increasing high density lipoprotein (HDL-C) (Belewu and Abodunrin, 2006). Daily consumption of TN has been shown to be effective in weight loss and improvement the metabolic disorders among obese diabetic patients (Salwa et al. 2010).

Polysaccharides content of JR and TN:

As shown in Figure (2) the polysaccharide content in JR and TN were defiantly different between each of them. Inulin was the most abundant in JR $(75.16 \mathrm{~g})$, follows by sucrose $(4.8 \mathrm{~g})$ and glucose $(1.5 \mathrm{~g})$. This result is also obtained by Franck (2000) who indicated that, JR is contains $95 \%$ inulin on dry matter. Fructose was the most abundant sugar in TN (13.5 g), follow by 
glucose and inulin (10.0 and $4.8 \mathrm{~g}$, respectively), therefore, TN is suitable for diabetes. Inulin and fructose considered as bioactive ingredients, which might be surprise as relevant to modify and improve the technical production of fermented milk and yoghurts. Inulin at ratio $2-4 \%$ is increase the firmness of fermented milk by Streptococcus and inoculated with Bifidobacterium lactis (Pinheiro et al. 2009). Gibson et al. (2004) reported that, the polysaccharide inulin is a soluble dietary fiber, which is not degraded by enzymes in the human digestive system, but fermented selectively by beneficial bacteria in the gut. Inulin and its degradation products are capable of stimulating and/or activating health-promoting bacterial growth in the colon. Moreover, inulin increases blood glucose level less than starch, and it is therefore suited as a constituent in an anti-diabetic diet (Rumessen et al., 1990).

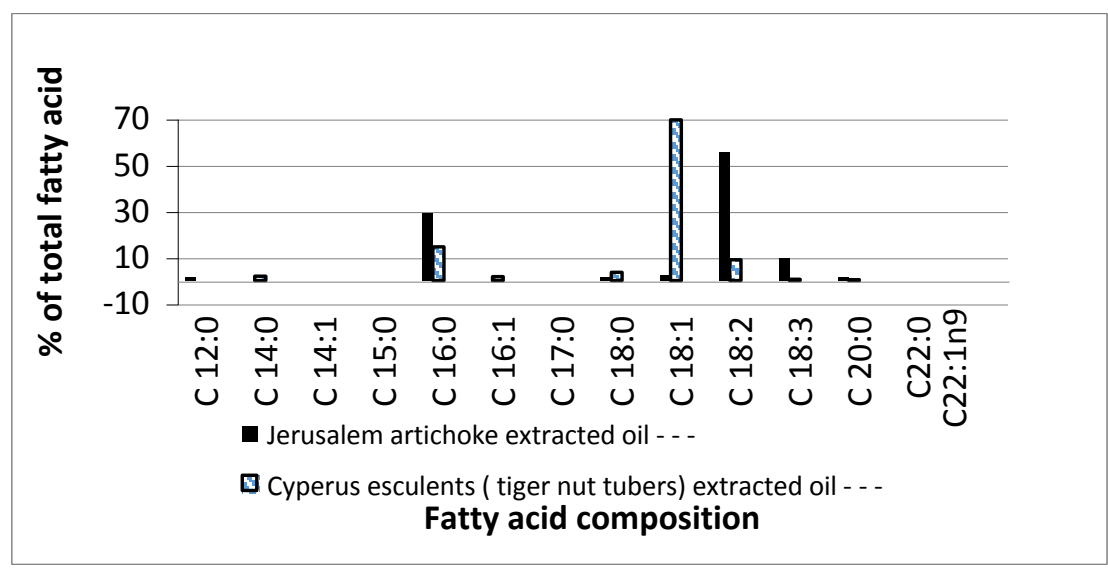

Fig 1. Fatty acids composition of JR and TN

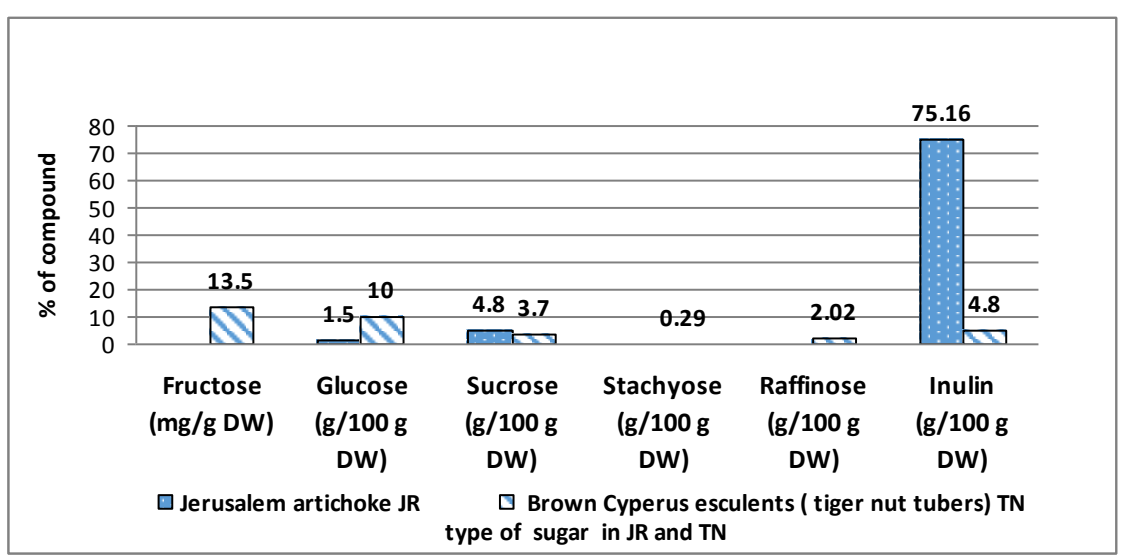

Fig 2. Polysaccharides content in Jerusalem artichoke and tiger nut tubers 


\section{Vitamins content in JR and TN:}

The most abundant vitamin compound in $\mathrm{JR}$ and $\mathrm{TN}$ were vit $\mathrm{E}$ and vit B1 and B2, these vitamins were the main task in human nutrition and antioxidant role in biological systems (Table 3). In terms of their nutrient content, the TN seeds compare richen in vitamin compare with those of JR; except for Vit B2, both plants seem capable of satisfying less than $6 \%$ of an adult's requirement for the various nutrients listed in Table (3). The TN provided an adequate quantity of Vitamins $\mathrm{E}$ and B1 about 54 and $21 \%$, respectively versus than RDV recommendation. A quite similar vitamin content in JR when compared to TN, vitamin E and Vit B1 accounted 47.33 and 13.27 as \% of RDV, respectively. The obtained results were agree with Belewu et al. (2007).

Table 3. Vitamins content in JA and TN (100 g dry base)

\begin{tabular}{|l|c|c|c|c|c|}
\hline \multirow{2}{*}{ Vitamins } & \multirow{2}{*}{ RDV* $^{*}$} & \multicolumn{2}{|c|}{ JR } & \multicolumn{2}{c|}{ TN } \\
\cline { 3 - 6 } & & Contents ** & \% of RDV & Contents ** & $\begin{array}{c}\text { \% of } \\
\text { RDV }\end{array}$ \\
\hline Vit B1 $(\mathrm{mg})$ & 1.50 & $0.199 \pm 0.48$ & 13.27 & $0.31 \pm 0.35$ & 20.67 \\
\hline Vit B2 $(\mathrm{mg})$ & 1.70 & $0.089 \pm 0.16$ & 5.24 & $0.10 \pm 0.63$ & 5.88 \\
\hline Vit E $(\mathrm{mg})$ & 15 & $7.1 \pm 0.19$ & 47.33 & $8.0 \pm 0.13$ & 53.33 \\
\hline Vit C $(\mathrm{mg})$ & 90 & $1.5 \pm 0.62$ & 1.67 & $5.4 \pm 0.02$ & 6.00 \\
\hline
\end{tabular}

${ }^{*}$ Relative daily value (RDV); from the Food and Nutrition Board (2002); ** Values represent the mean $\pm S D$ of triplicate measurements

\section{Minerals content in JR and TN:}

Minerals content in JR and TN illustrated in (Table 4), JR contained a relatively large amount of micronutrient and macro nutrient elements than in TN such as $\mathrm{Zn}, \mathrm{Mo}, \mathrm{P}$ and $\mathrm{Cu}$ accounting $(17.17,11.92,370$ and $5.35 \mathrm{mg} / \mathrm{kg}$ dry weight, respectively). However, TN was containing a considerable amount of sulfur, $\mathrm{Mn}, \mathrm{Ca}, \mathrm{Mg}$ and $\mathrm{Fe}$ (1369, 11.39, 150, 132.3 and 131.5 $\mathrm{mg} / \mathrm{kg}$ on dry base, respectively). These minerals are important for human. $100 \mathrm{~g}$ of $\mathrm{JR}$ provide a sufficient amount more than quarter ratio of copper USDA recommend. Both of JR and TN are good sources of Fe, Zn, and Mg, while TN is only contain a higher ratio of $\mathrm{Cu}$. These elements are very important in human malnutrition and diabetic diseases (Edem et al. 2009). Iron is necessary for the prevention of anemia, and zinc necessary for nucleic acid metabolism, protein synthesis and cell growth (Igoe 1989). Molybdenum is an essential element in human nutrition, its enhanced stress response in human body which exposure to xenobiotic compounds and involves detoxification of these compounds (Luo et al. 1983).

Table 4. Mineral contents of JR and TN.

\begin{tabular}{|l|c|c|c|c|c|c|c|c|c|}
\hline \multicolumn{10}{|c|}{ Minerals $\mathbf{~ m g / k g}$} \\
\hline & Ca & $\mathbf{P}$ & $\mathbf{M g}$ & $\mathbf{M o}$ & $\mathbf{F e}$ & $\mathbf{Z n}$ & $\mathbf{C u}$ & $\mathbf{M n}$ & $\mathbf{S}$ \\
\hline JR & 120 & 370 & 1127 & 11.92 & 117.2 & 17.17 & 5.35 & 10.84 & 1250 \\
\hline TN & 150 & 330 & 1323 & 9.75 & 131.5 & 12.11 & ND & 11.39 & 1369 \\
\hline RDV-(mg) & 1000 & 1000 & 400 & 75 & 18 & 15 & 2.0 & 2.0 & - \\
\hline
\end{tabular}

${ }^{*}$ Relative daily value (RDV); from the Food and Nutrition Board (2002) 


\section{GC-MS analysis in JR and TN:}

Data from the analysis of $\mathrm{JR}$ and TN volatile components are illustrated in Table (5). It showed that, 20 compounds in JR, and 18 compounds in TN were tentatively identified. Most of these methanolic extract from two plants are bosses as bioactive compounds and antimicrobial agents. The largest portion of GC-MS profile of JR was propionic acid, nonal ester (29.605\%), followed by D-allothreonine (11.84\%) and Acetic acid, ethoxyhydroxy-, ethyl ester (10.526\%). D-allothreonine is one of essential amino acid, which maintains phospholipid metabolism and physiology in liver cells (Kathayat et al. 1997). The largest portion of GC-MS profile in TN was I-(+)-Ascorbic acid 2,6-dihexadecanoate $(40.773 \%)$, followed by 2-Butenedioic acid (E)-, bis(2ethylhexyl ester (13.305\%) and palmitic acid (10.730\%) of total identified GC MS compound. Moreover, TN contains hydrocarbon compounds such as BCymene, D-Limonene and Psi-limonene in ranged between 1.5-2.57\% from total GC-Ms profile. This result is agree with Kubmarawa et al. (2005) who reported that, TN contained high amounts were $\rho$-cymene $(1.3-2.8 \%)$, limonene (1.3-2.8\%), myrcene (1.7-1.8\%) and sabinene (1.0-6.9\%). BCymene, which has a biological role in antimicrobial activity, as well as two aromatic alcohols of O-thymol and menthol were identified in TN.

Huisman et al. (2004) reported that, JR contained many important alcoholic compounds such (-)-isopulegol, 2-p-cymenol, thymol acetate and geranyl isovalerate, these alcoholic material exhibited antioxidant properties. Caryophyllene compound such as $\gamma$-Gurjunene has been identified in JR at ratio $3.947 \%$ of total identified GC-MS compounds. Several biological activities attributed to $\beta$-caryophyllene, such as anti-inflammatory, antibiotic, antioxidant, anticarcinogenic and local anaesthetic activities. This result agree with Legault and Pichette (2007). In addition, caryophyllene oxide recognized as stabilizer in foodstuff, drugs and cosmetics and has shown growth inhibiting activity against dermatophytes (Yang et al. 1999). It has also shown growth inhibitory effects on Staphylococcus aureus (Katsuyama et al. 2005). Thymol (phenolic monoterpenes) was identified in both plant of JR and $\mathrm{TN}$. It has relatively strong antimicrobial activities (Burt 2004). It was synergistically active against $E$. coli strains acting by thymol disintegrated the outer membrane of E. coli (Lambert et al. 2001).

Fatty acid (FA) composition of bio-yoghourt:

Table (6) represents the overall FA composition in bio-yoghourt fortified with JR or TN flour, 17 FA detected, comprised of both saturated and unsaturated FA. Long chain FA profile of control bio-yoghourt shows Palmitic (C16:0), oleic acid (C18:1), myristic (C16:0) and stearic acids (C18:0) being relatively high. Relative proportion of different FA is underwent changes during processing. Fortified bio-yoghurt with $\mathrm{JR}$ induced changes than control yoghurt, where it decreased oleic acid (8.44), increased low molecular FA as caproic (C6:0) and caprileic acid, (C8:0), as well as increased linoleic acid (C18:2n6) up to $18.17 \%$, which is 6 times more than the amount in the control sample. 
El-Reffaei, W. H. M. et al.

Table 5. GC-MS components of JR and TN methanol extract.

\begin{tabular}{|c|c|c|c|c|}
\hline RT & Compound name in JR & Peak area \% & Compound name in TN & Peak area \% \\
\hline 3.22 & Propionic acid, nonal ester & 29.605 & & \\
\hline 3.23 & & & $\begin{array}{l}\text { 2-Butenedioic acid (E)-, } \\
\text { bis(2-ethylhexyl ester }\end{array}$ & 13.305 \\
\hline 3.31 & Butanoic acid , 2,4-diamino & 4.934 & & \\
\hline 3.71 & $\begin{array}{l}\text { Acetic acid, ethoxyhydroxy-, } \\
\text { ethyl ester }\end{array}$ & 10.526 & & \\
\hline 3.81 & D-allothreonine & 11.842 & & \\
\hline 4.75 & & & O-thymol & 1.073 \\
\hline 6.36 & & & $\begin{array}{c}\text { Acetic acid, 2,2- } \\
\text { \{oxybis(2,1-ethyl)ester }\end{array}$ & 1.073 \\
\hline 6.81 & Phenol, 4-(2-aminopropyl) & 2.303 & & \\
\hline 7.04 & & & B-Cymene & 2.146 \\
\hline 7.09 & & & D-Limonene & 2.575 \\
\hline 8.15 & (-)- ISOPULEGOI & 2.303 & & \\
\hline 8.16 & & & Psi-limonene & 1.502 \\
\hline 9.31 & & & Menthol, $( \pm)-$ & 2.146 \\
\hline 9.41 & & & Cis-B-Terpinenol & 0.858 \\
\hline 9.67 & & & $\begin{array}{c}\text { Benzoic acid, 2-hydroxy-, } \\
\text { hydrazide }\end{array}$ & 3.863 \\
\hline 10.70 & $\begin{array}{l}\text { Methoxyacetic acid, 2- } \\
\text { pentadecyl ester }\end{array}$ & 1.645 & & \\
\hline 10.22 & 2-P-CYMENOL & 2.303 & & \\
\hline 10.92 & & & Anethole & 0.773 \\
\hline 11.1 & & & Carvacryl acetate & 6.438 \\
\hline 11.12 & & & $\begin{array}{c}\text { 5-Isopropenyl-2-methyl-2- } \\
\text { cyclohexen-1-one }\end{array}$ & 5.579 \\
\hline 11.3 & Thymol acetate & 2.467 & & \\
\hline 12.25 & Geranyl isovalerate & 1.974 & & \\
\hline 12.92 & $\begin{array}{c}\text { Methoxyacetic acid, 3- } \\
\text { tetradecyl ester }\end{array}$ & 1.974 & & \\
\hline 13.47 & Eicosane,10-Methyl & 1.974 & & \\
\hline 13.73 & $\gamma$-Gurjunene & 3.947 & & \\
\hline 13.99 & & & Geranyl isovalerate & 0.773 \\
\hline 14.73 & & & $\begin{array}{c}\text { Butyric acid, 4-pentadecyl } \\
\text { ester }\end{array}$ & 1.073 \\
\hline 14.74 & $\begin{array}{c}\text { Butyric acid, 4-pentadecyl } \\
\text { ester }\end{array}$ & 4.934 & & \\
\hline 15.9 & $\begin{array}{c}\text { TETRADECANE, 2,6,10- } \\
\text { TRIMETHYL } \\
\end{array}$ & 1.974 & & \\
\hline 16.36 & TRICOSANE & 3.947 & & \\
\hline 16.47 & & & Stearic acid & 1.717 \\
\hline 18.13 & OCTADECANE & 3.618 & & \\
\hline 18.13 & & & $\begin{array}{c}\text { Hexadecanoic acid, methyl } \\
\text { ester }\end{array}$ & 3.433 \\
\hline 18.6 & Nonahexacontanoic acid & 2.303 & & \\
\hline 18.71 & $\begin{array}{c}\text { Phthalic acid, isobutyl } \\
\text { octadecyl ester }\end{array}$ & 2.632 & & \\
\hline 18.74 & & & $\begin{array}{l}\text { I-(+)-Ascorbic acid 2,6- } \\
\text { dihexadecanoate }\end{array}$ & 40.773 \\
\hline 18.92 & $\begin{array}{c}\text { Hexadecanoic acid, methyl } \\
\text { ester }\end{array}$ & 2.632 & & \\
\hline 18.93 & & & Palmitic acid & 10.730 \\
\hline
\end{tabular}

Linoleic acids (CLA) has attributed as anticarcinogenic properties, as well as antiatherogenic effects, and also known as rumenic acid (Masso- 
Welch et al. 2004). Fortified bio-yoghurt with TN showed higher oleic acid and lower C18:2n6 than found in JR bio-yoghurt. Fortified bio-yoghurt with TN increased oleic acid from $22.35 \%$ in control to $35.70 \%$, as well as increased CLA up to $7.10 \%$, while decreased Stearic acid than control bio-yoghurt. Low molecular FA is lower in TN bio-yoghurt than in control and JR bio-yoghurt. These FA are responsible to improve aroma of processed yoghurt. It seems that individual fatty acids followed different pattern of changes during processing or fermentation. Therefore, it assumed that, fortification bioyoghurt containing probiotic bacteria with $\mathrm{JR}$ or TN led to improve growth of probiotic bacteria and produce important CLA, which has anticancer and anti hypercholestrolemic activities.

Table 6. Fatty acid composition of bio-yoghourt fortified with JR or TN flour.

\begin{tabular}{|l|c|c|c|}
\hline Fatty acids & Control & Fortified with JR & $\begin{array}{c}\text { Fortified with } \\
\text { TN }\end{array}$ \\
\hline Caproic Acid, C6:0 & 2.02 & 3.29 & 2.25 \\
\hline Caprilic Acid, C8:0 & 1.19 & 2.28 & 0.25 \\
\hline Capric Acid, C10:0 & 4.28 & 3.19 & 2.48 \\
\hline Lauric Acid, C12:0 & 4.16 & 3.22 & 1.17 \\
\hline Myristic Acid, C14:0 & 12.38 & 10.24 & 9.28 \\
\hline Myristoleic Acid, C14:1 & 1.16 & 2.25 & 2.28 \\
\hline Pentadecanoic Acid, C15:0 & 2.18 & 0.99 & 0.72 \\
\hline Palmitic Acid, C16:0 & 27.87 & 25.23 & 28.59 \\
\hline Palmitoleic Acid, C16:1 & 1.95 & 0.50 & 0.33 \\
\hline Heptadecanoic Acid, C17:0 & 1.41 & 0.23 & 0.28 \\
\hline Stearic Acid, C18:0 & 10.28 & 12.15 & 6.24 \\
\hline Oleic Acid, C18:1n9c & 22.35 & 8.44 & 35.70 \\
\hline Linoleic Acid, C18:2n6 & 3.62 & 18.17 & 7.12 \\
\hline Linolenic Acid, C18:3n3 & 3.84 & 8.69 & 2.78 \\
\hline Arachidic Acid, C20:0 & 0.22 & 0.59 & 0.23 \\
\hline Behenic Acid, C22:0 & 0.87 & 0.54 & 0.16 \\
\hline Eurcic Acid C22:1n9 & 0.22 & - & 0.14 \\
\hline
\end{tabular}

Texture profile of bio-yoghurt fortified with JR and TN:

The instrumental texture profile of bio- yoghurt fortified with $10 \%$ of JR or TN have shown in Table (7). There was an increase in all texture parameters analyzed. Firmness of fortified bio-yoghurt was increased from 5.55 for control to 8.21 and 9.22 for JR and TN, respectively. There is no variation between fortified bio-yoghurt with JA or TN, whereas, there were increase in cohesiveness compare to control bio-yoghurt. Gumminess, chewiness and springiness of different bio-yoghurts $2.16,1.08$ and 0.33 to 2.22, 1.29 and 0.48 , respectively showed differences between JR and TN bio-yoghurt. The stability of texture profile was desirable to maintain physical-chemical and sensory properties after fermentation and storage period. The increase in firmness may be related to dietary fiber absorbing more moisture because of 
its higher water-holding capacity (Hashim et al. 2009), and oil-holding capacity, emulsification and/or gel formation. (Elleuch et al. 2011). It has been suggested that inulin is a water-structuring agent and it may form a complex with protein aggregates in yoghurt, which could explain the increase in firmness in these products (Kip et al., 2006). Similar to Srisuvor et al. (2013) and Oliveira et al. (2011) inulin addition to co-cultures and cocktail enhanced products firmness, either after 1 day or 7 days of cold storage, likely due to the increase in microbial growth induced by metabolic interactions among lactic acid bacteria and partial inulin metabolization. Moreover, Tamime (2005) found that the higher microbial growth is one of the causes of a firmness increase in yoghurt.

Table 7. Texture profile analysis of bio-yoghurt fortified with JR or TN (10\%) flour

\begin{tabular}{|l|c|c|c|}
\hline Texture profile & Control & $\begin{array}{c}\text { Fortified with } \\
\text { JR }\end{array}$ & $\begin{array}{c}\text { Fortified with } \\
\text { TN }\end{array}$ \\
\hline Firmness $(\mathrm{N})$ & $5.55 \pm 0.29$ & $8.21 \pm 1.35$ & $9.22 \pm 0.99$ \\
\hline Cohesiveness & $0.25 \pm 0.22$ & $0.78 \pm 0.11$ & $0.79 \pm 0.18$ \\
\hline Gumminess $(\mathrm{g})$ & $1.28 \pm 0.13$ & $2.16 \pm 1.47$ & $2.22 \pm 1.14$ \\
\hline Chewiness $(\mathrm{g} \times \mathrm{mm})$ & $0.39 \pm 0.04$ & $1.08 \pm 1.31$ & $1.29 \pm 0.90$ \\
\hline Springiness $(\mathrm{mm})$ & $0.24 \pm 0.12$ & $0.33 \pm 0.09$ & $0.48 \pm 0.78$ \\
\hline
\end{tabular}

Table 8. Organoleptic evaluation for bio yogurts fortified with $10 \%$ JR or TN

\begin{tabular}{|l|c|c|c|}
\hline Taste parameter & Control & $\begin{array}{c}\text { Fortified with } \\
\text { biofedobacterium } \\
\text { and JR }\end{array}$ & $\begin{array}{c}\text { Fortified with } \\
\text { biofedobacterium and } \\
\text { TN }\end{array}$ \\
\hline Sourness & $6.3 \pm 1.9$ & $6.5 \pm 2.2$ & $5.3 \pm 1.2$ \\
\hline Bitterness & $4.2 \pm 1.2$ & $3.1 \pm 0.7$ & $2.2 \pm 1.6$ \\
\hline Sweetness & $2.6 \pm 1.6$ & $4.3 \pm 1.5$ & $5.7 \pm 1.0$ \\
\hline Aroma & $6.3 \pm 0.8$ & $4.2 \pm 1.7$ & $5.8 \pm 2.1$ \\
\hline $\begin{array}{l}\text { Overall } \\
\text { acceptability }\end{array}$ & $6.7 \pm 0.2$ & $5.3 \pm 1.8$ & $7.1 \pm 1.7$ \\
\hline
\end{tabular}

\section{Organoleptic evaluation for bio- yogurts:}

Results from Table (8) showed organoleptic evaluation of bio-yoghurt fortified with $10 \%$ of JR or TN. Sourness was decrease in fortified TN. The TN bio-yoghourt was lower in brightness than control and JR bio-yoghurt. Characteristics of color of fortified TN were naturally brown, which affect the overall color and brightness. Increasing of sweetness in TN bio-yoghurts attributes to the level of sweeteners of fructose and glucose content in TN compared to control and JR yoghurts. Bio-yoghurt fortified with JR has impassive in aroma than control and TN yoghurt. There was a defiantly higher overall acceptability in TN than control and JR bio-yoghurt. These contribute to that TN composite was contain a higher ratio of natural 
sweeteners with lowering of sourness. The addition of each prebiotic could improve

physical and sensory properties of the yoghurt, by stimulating growth of probiotic bacteria (Srisuvor et al. 2013). Moreover, Decourcelle et al. (2004) mentioned that conducted those probiotic yoghourts with high level of TN characterized with softness and sweet flavor.

\section{Rheological properties of dough:}

The results obtained from alveographic measurement of wheat flour (WF) substituted with JR and TN summarized in Table (9). Substitute WF with 5,10 and $15 \%$ of JR or TN evaluated as weaker with lower tenacity and baking strength parameters. Wheat flour is able to form cohesive dough having viscoelastic properties and possessing the ability to retain gas, prepared from these flours at different ratio of substitutions did not have optimal viscoelastic behavior, as described by the lower in Configuration rate $(\mathrm{P} / \mathrm{L})$ percentage. These results are presented the dough rheological behavior during fermentation and baking. Therefore, the Alveograph device allows the measurement of gluten deformation. Its mode of deformation is similar to the extension that takes place during fermentation and oven rise.

The baking strength representing the energy necessary to inflate the dough bubble to the point of rupture ranged from 160 in the control wheat flour $(100 \%)$ to 36.0 in the ratio $15 \%$ TN substitution in WF. Such a weakening tendency of the dough for blends JR or TN with flours substitution with low tenacity values is characteristics to the presence of a low molecular weight dextrin produced by hydrolyses of damaged wheat flour starch during fermentation assay. Generally, elastic modulus, extendibility, index of swelling, baking strength, configuration rate were lower than present in control $100 \%$ wheat flour. Wang et al. (2002) reported a decrease in dough elasticity, determined by a farinograph test, upon addition of $3 \%$ chicory inulin (Collar et al. 2007). The addition of 10 and $15 \%$ of JR or TN has produced worst quality of dough elasticity and extensibility. This result is worth mentioning that addition ratio of JR and TN at $5 \%$ have a little closest of Alveograph parameters with $100 \%$ wheat flour dough.

\section{Microbiological evaluation:}

Effect of $J R$ and $T N$ on some probiotic bacteria in vitro:

The results recorded in Table (10) clearly showed that JR at concentration $10 \%$ encouraged growth of $L$. plantarum ; L. curvatus and $B$. subtilis in enrichment broth medium and following by increasing counts of $L$. plantarum from $4 \times 10^{13}$ to $3 \times 10^{17}$, L. curvatus from $4 \times 10^{13}$ to $4 \times 10^{17}$ and $B$. subtilis from $4 \times 10^{11}$ to $4 \times 10^{16} \mathrm{cfu} / \mathrm{ml}$, while $\mathrm{TN}$ at concentration 10 $\%$ increased counts of $L$. plantarum from $4 \times 10^{13}$ to $8 \times 10^{16}, L$. curvatus from $4 \times 10^{13}$ to $4 \times 10^{17}$ and $B$. subtilis from $4 \times 10^{11}$ to $13 \times 10^{16} \mathrm{cfu} / \mathrm{ml}$ in enrichment broth medium. The concentration $10 \%$ of JR or TN represented the optimum concentration for enhancing the growth of the three-probiotic strains and led to decreasing pathogenic bacteria by reduction acidity. Fortified yoghurt by JR or TN, improved carbohydrate content and prebiotic inulin, which contributed to increase activity of Lactobacillus plantarum and 
Table 9. Rheological properties of wheat flour (WF) dough supplemented with different concentration of JR or TN

\begin{tabular}{|l|c|c|c|c|c|c|c|}
\hline \multirow{2}{*}{$\begin{array}{l}\text { Flour } \\
\text { alveograph } \\
\text { properties }\end{array}$} & WF & \multicolumn{3}{|c|}{ JA } & \multicolumn{3}{|c|}{ TN } \\
\cline { 2 - 8 } & $100 \%$ & $5 \%$ & $10 \%$ & $15 \%$ & $5 \%$ & $10 \%$ & $15 \%$ \\
\hline $\begin{array}{l}\text { Tenacity (P) } \\
\text { mm } \mathrm{H}_{2} \mathrm{O}\end{array}$ & 85.7 & 76.0 & 54.0 & 38.00 & 89.0 & 44.00 & 46.00 \\
\hline $\begin{array}{l}\text { Extensibility } \\
(\mathrm{L}) \mathrm{mm}\end{array}$ & 53.1 & 46.0 & 41.0 & 29.00 & 29.0 & 32.0 & 18.0 \\
\hline $\begin{array}{l}\text { Index of } \\
\text { swelling (G) }\end{array}$ & 17.2 & 15.1 & 14.3 & 12.0 & 12.0 & 12.6 & 9.4 \\
\hline $\begin{array}{l}\text { Baking } \\
\text { strength } \\
\text { (W)10E-4 J }\end{array}$ & 160.8 & 151.0 & 94.00 & 46.0 & 113.0 & 57.00 & 36.0 \\
\hline $\begin{array}{l}\text { Configuration } \\
\text { rate (P/L) \% }\end{array}$ & 1.77 & 1.65 & 1.32 & 1.31 & 3.07 & 1.38 & 2.56 \\
\hline $\begin{array}{l}\text { Elasticity } \\
\text { index (le) \% }\end{array}$ & 75.6 & 60.00 & 51.4 & 45.20 & 55.6 & 43.8 & 36.15 \\
\hline
\end{tabular}

Table 10. Effect of JR and TN on some probiotic bacteria counts in vitro

\begin{tabular}{|l|c|c|c|c|}
\hline \multirow{2}{*}{ without } & \multicolumn{3}{|c|}{ Treatments $^{*}$} & \multicolumn{2}{c|}{ TN } \\
\cline { 2 - 5 } & $\mathbf{5 \%}$ & $\mathbf{1 0 \%}$ & $\mathbf{5 \%}$ & $\mathbf{1 0 \%}$ \\
\hline $\begin{array}{l}\text { L. plantarum } \\
7 \times 10^{13} \mathrm{cfu} / \mathrm{ml}\end{array}$ & $2 \times 10^{15}$ & $3 \times 10^{17}$ & $3 \times 10^{16}$ & $8 \times 10^{16}$ \\
\hline $\begin{array}{l}\text { L. curvatus } \\
9 \times 10^{13} \mathrm{cfu} / \mathrm{ml}\end{array}$ & $3 \times 10^{16}$ & $4 \times 10^{17}$ & $5 \times 10^{16}$ & $4 \times 10^{17}$ \\
\hline $\begin{array}{l}\text { B. subtilis } \\
9 \times 10^{11} \mathrm{cfu} / \mathrm{ml}\end{array}$ & $5 \times 10^{14}$ & $4 \times 10^{16}$ & $10 \times 10^{14}$ & $13 \times 10^{16}$ \\
\hline
\end{tabular}
and $B$. subtilis was $4 \times 10^{11} \mathrm{cfu} / \mathrm{ml}$

Lactobacillus curvatus than control yoghurt. This also recorded by Buriti et al. (2010a) and Komatsu et al. (2013).

Effect of JR and TN on growth and survival of Staph aureus in vitro:

The obtained results in Table (11) showed that, JR and TN at concentration $10.0 \%$ resulted in decrease of Staph aureus counts from $7 \times$ $10^{13}$ to $6 \times 10^{7}$ and $5 \times 10^{6} \mathrm{cfu} / \mathrm{ml}$, respectively in vitro and to $9 \times 10^{4}$ and $7 \times$ $10^{3} \mathrm{cfu} / \mathrm{g}$, respectively in yoghurt. On the other hand, non-fortified yoghurt samples showed reduced Staph aureus counts from $7 \times 10^{13}$ to $2 \times 10^{9} \mathrm{cfu} / \mathrm{g}$, these results in agreement with the studies of Mattila -Sandholm et al. (2002) and Dimitroglou et al. (2011) which recorded that, probiotics prevent and control of pathogenic microorganisms as an alternative against traditional disease control such as chemotherapeutic agents or vaccines (Dimitroglou et al. 2011). The addition of each prebiotic could improve physical and sensory properties of the yoghurt, by stimulating growth probiotic bacteria (Srisuvor et al. 2013). Inulin addition to co-cultures and cocktail enhanced products firmness, either after 1 day or 7 days of cold storage, likely due to the 
increase in microbial growth induced by metabolic interactions among lactic acid bacteria and partial inulin metabolization (Oliveira et al. 2011). Stimulatory effect of inulin on the growth of bifidobacteria and lactobacilli (Akalin et al. 2004), has recently been described to greater release in yoghurt of additional nutrients (Makras et al. 2005). Moreover, probiotics can inhibit pathogen multiplication, where low numbers of Lactobacillus delbrueckii would help the survival of probiotic organisms due to reduced risks of post acidification by Lactobacillus delbrueckii (Shah 1995). In addition, inulin powder improved Lactobacillus casei growth during fermentation and their survival during storage time (Aryana and McGrew 2007), higher counts of probiotic bacteria in yoghurts with medium and long Chain inulin than those with oligofructose at the end of storage (Lankaputhra et al. 1996).

Table (11): Effect of JR and TN on growth and survival of Staph aureus *in vitro

\begin{tabular}{|l|c|c|c|c|}
\hline \multicolumn{4}{|c|}{ Treatments $^{*}$} \\
\cline { 2 - 5 } without & $\mathbf{5 . 0 \%}$ & $\mathbf{1 0 . 0} \%$ & $\mathbf{5 . 0 \%}$ & $\mathbf{1 0 . 0 \%}$ \\
\hline In vitro $9 \times 10^{13} \mathrm{cfu} / \mathrm{ml}$ & $3 \times 10^{9}$ & $6 \times 10^{7}$ & $4 \times 10^{7}$ & $5 \times 10^{6}$ \\
\hline Yoghurt $2 \times 10^{9} \mathrm{cfu} / \mathrm{g}$ & $4 \times 10^{6}$ & $9 \times 10^{4}$ & $3 \times 10^{4}$ & $7 \times 10^{3}$ \\
\hline
\end{tabular}

${ }^{\star}$ The used inoculum for Staph aureus was $7 \times 10^{13} \mathrm{cfu} / \mathrm{ml}$

The supplementation inulin from Jerusalem artichoke resulted in greater growth rates of Lactobacillus casei than Bifidobacterium bifidum and Lactobacillus acidophilus during cold storage of yoghurt (Paseephol and Sherkat, 2009). The mechanism by which inulin improve the viability of the probiotic organisms during cold storage is still unclear, while the two possible mechanisms proposed so far state that inulin's provide additional nutrients for promoting culture growth (Makras et al. 2005), and that they protect probiotic cells from acid injury (Desai et al. 2004). The addition of inulin reduced the fermentation time by about $10.0 \%$ as an average, thus confirming its prebiotic effect already evidenced for both biofidobacteria and lactobacilli by (Donkor et al. 2007). The higher microbial growth is one of the causes of a firmness increase in yoghurt (Tamime, 2005), while some other publications by Ozer et al. (2005) reported, that inulin didn't support the growth and survival of $L$. acidophilus in fermented bovine milk and acidophilus-bifidus yoghurts.

\section{CONCLUSION}

The results from this study revealed that TN oil contains FA similar of olive oil. Adding JR and TN in bio-yoghurts improve nutritional values, probiotic bacteria and the stability of texture profile, which is desirable to maintain physical-chemical and sensory properties after fermentation and storage period. In addition, substitution of JR and TN in white flour WF improve nutritional quality and lowering gluten composite, which is suitable for Celiac disease patients. $10.0 \%$ supplementation level of JR and TN 
resulted in greater rates of probiotic bacteria growth in vitro, and showed stronger antimicrobial activity against Staph aureus in vitro and processed yoghurt. Overall results suggest that JR and TN are a potential functional food ingredient that may be used in food applications.

\section{REFERENCES}

AACC, (2000). Approved Methods of the American Association of Cereal Chemist, 10th edn. The American Association of Cereal Chemist, St Paul, MN.

Abrams, S. A., Griffin, I. J., Hawthorne, K. M., Liang, L., Gunn, S. K., Darlington, G., (2005).A combination of prebiotic short- and longchain inulin-type fructans enhances calcium absorption and bone mineralization in young adolescents. American Journal of Clinical Nutrition, 82, 471-476.

Adejuyitan, J. (2011). Tiger nut processing its food uses and health benefits. American Journal of Food Technology, 6 (3):97-201.

Aguilar, N., E. Albanell, B. Minarro and M. Capellas, (2015). Chickpea and tiger nut flours as alternatives to emulsifier and shortening in glutenfree bread. LWT-Food Sci. Technol., 62: 225-232.

Akalin A. S., S. Fenderya, and N.Akbulut (2004). Viability and activity of biofidobacteria in yoghurt containing fructooligosaccharide during refrigerated storage. International of Food Science and Technology. 39:613-621.

Alsmeyer, R.H.; A.E. Cumninghan, and M.L. Happich, (1974). Equations predict PER from amino acid analysis. Food Technol. 7: 34-40.

AOAC, (2012)."Official Methods of Analysis". 19 th ed. Gaithersburg, MD: AOAC International,

Aryana, K., and P. Mcgrew (2007). Quality attributes of yoghurt with Lactobacillus casei and various prepiotics. LWT-Food Science and Technology, 40, 1808-1814.

Alsmeyer, R.H.; Cumninghan, A.E. and Happich, M.L. (1974) Equations predict PER from amino acid analysis. Food Technol. 7: 34-40.

Bourne, M. C. (2002) Food Texture and Viscosity: Concept and Measurement, 2nd edn., Academic Press, San Diego CA.

Belewu, M.A. and O.A. Abodunrin (2006). Preparation of Kunnu from unexploited rich food source: Tigernut (Cyperus esculentus). World J. Dairy Food Sci., 1: 19- 21.

Belewu, M.A., and K.Y. Belewu (2007). Comparative Physico- Chemical evaluation of tiger- nut, soybean and coconut milk sources. International Journal of Agriculture and Biology, 5: 785-787.

Berrang, M. E.; R. J.Buhr , J.Cason,, and A. Dickens (2001). Broiler carcass contamination with Campylobacter from feces during defeathering. J. Food Prot., 64:2063-2066.

Bognar, A. (1992). Determination of vitamin B1 in food by high-performance liquid chromatography and post-column derivatization. Fresenius $\mathrm{J}$ Anal Chem, 343:155-156. 
Boskou, D.; B. G.Lekas And M. Tsimidou (2005). Phenolic compounds in olive and olives current topics in nutraceuticals Research. 3:125-136. (Cited from Boskou, D. (2006). Sources of natural phenolic antioxidants. Trend in Food Sci and Technology, 17:505-512.

Bourne, M. C. (2002) Food Texture and Viscosity: Concept and Measurement, 2nd edn., Academic Press, San Diego CA.

Burt, S. (2004). Essential oils: their antibacterial properties and potential applications in foods review. International Journal of Food Microbiology, 94:223-253.

(2002) Food Texture and Viscosity: Concept and Measurement, 2nd edn., Academic Press, San Diego CA.Buriti, F.C.A., I.A.Castro and S.M.I. Saad (2010). Effects of refrigeration, freezing and replacement of milk fat by inulin and whey protein concentrate on texture profile and sensory acceptance of synbiotic guava mousses. J Food Chem, 23:1190-1197

Cabezas, M.J., C. Rabert, , S. Bravo, and C. Shene (2002). Inulin and Sugar Contents in Helianthus tuberosus and Cichorium intybusTubers: Effect of Postharvest Storage Temperature. Journal of Food Science 67 (8): 2860-2865.

Campos, F. M., S. M. R. Ribeiro, C. M.Della Lucia,, H. M.Pinheiro-Sant'ana, , and P. C. Stringheta, (2009). Optimization of methodology to analyze ascorbic and dehydroascorbic acid in vegetables. Química Nova, 32(1):87-91.

Codina-Torrella, I., B.Guamis, and A. J. Trujillo, (2014). Characterization and comparison of tiger nuts (Cyperus esculentus L.) from different geographical origin: Physico-chemical characteristics and protein fractionation. Industrial Crops and Products. 11-7.

Collar, C., C. Santos, and M Rosell (2007). Assessment of the rheological profile of fiber-enriched bread doughs by response surface methodology. Journal of Food Engineering, 78(3): 820-826.

Cruz, A.G., R.S.Cadena,, E.H.M. Walter, , A.M.Mortazavian, D. Granato, , J. .A.F. Faria, and H.M.A. Bolini, (2010). Sensory analysis: relevance for prebiotic, probiotic, and synbiotic product development. Comprehensive Reviews in Food Science and Food Safety 9(4), 358373.

Decourcelle, N., S. Lubbers,, N. Vallet, , P.Rondeau and E. Guichard, (2004). Effect of thickeners and sweeteners on the release of blended aroma compounds in fat-free stirred yoghurt during shear conditions. Int. Dairy J., 14:783-789.

Desai, A. R., I. B., Powell, and N. P. Shah, (2004).Survival and activity of probiotic lactobacilli in skim milk containing prebiotics. Journal of Food Science, 69: 57-60.

Dimitroglou A., D. L. Merrifield, O. Carnevali, S.Picchietti, M.Avelia, and C. Daniels(2011).Microbial manipulations to improve fish health and production a Mediterranean perspective. Fish Shellfish Immunol,20:116. 
Donkor, O. N., S. L. I. Nilmini, P.Stolic, T. Vasiljevic and N. P. Shah, (2007). Survival and activity of selected probiotic organisms in set-type yoghurt during cold storage. International Dairy Journal, 17: 657-665.

Dubois, V, S. Breton,, M Linder, J Fanni, and M.Parmentier (2007). Fatty acid profiles of 80 vegetable oils with regard to their nutritional potential. Eur J Lipid Sci Technol 109: 20-32.

Edem, Christopher A. Dosunmu, Miranda, I., Bassey and I.Francesca, (2009). Determination of Proximate Composition, Ascorbic Acid and Heavy Metal Content of African Walnut (Tetracarpidium conophorum).Pak.J. Nutrit. 8: 225-226.

Elleuch, M., D.Bedigian, , O.Roiseux, , S Besbes, C.Blecker, and H. Attia (2011). Dietary fiber and fiber-rich by-products of food processing: characterization,technological functionality and commercial applications: a review. Food Chem 124: 411-421.

FAO/WHO, (1991). Protein quality evaluation in human diets. Report of a joint FAO/WHO Expert Consultation. FAO Food and Nutrition paper 51. Food and Agriculture Organization, Rome.

Food and Nutrition Board (2002). Dietary reference intakes for energy, carbohydrate, fiber, fat, fatty acids, cholesterol, protein, and amino acids. Washington, DC; National Academy Press.

Franck, A. M. E. (2000). Inulin and oligofructose. In G. R. Gibson \& F. Angus (Eds.), LFRA ingredient handbook: Prebiotics and probiotics (pp. 118). Surrey: Leatherhead Publishing.

Gibson, G. R., J H. Probert, M. R. A.Vanloorastall, , M. B. Roberfroid (2004). Dietary modulation of the human colonic microbiota: updating the concept of prebiotics. Nutrition Research Reviews, 17:259-275

Hashim I.B., A.H Khalil, and H.S. Afifi, (2009).Quality characteristics and consumer acceptance of yogurt fortified with date fiber .J Dairy Sci 92:5403-5407.

Helle Ruresson, Salla Marttila, Karl -Erik Gustavsson, Per Hofvander (2010). American Journal of Botany 97(11): 11-15.

Huisman, A., A.Van De Wiel, , T. J.Rabelink, , and E. E Van Faassen, (2004). Wine polyphenols and ethanol do not significantly scavenge superoxide nor affect endothelial nitric oxide production. Journal of Nutritional Biochemistry, 15:426-432.

Igoe, R.S. (1989). Dictionary of Food Ingredients. New York: Vas Nost and Reinhoed.

IIFC, (2004). Background on functional foods. http://www.ific.org/nutrition/ functional/ upload/FuncFdsBackgrounder.pdf

Javier M., J. María Encinar, J. González, and R. A. Barrena .(2011). Analysis of sugars by liquid chromatography-mass spectrometry in Jerusalem artichoke tubers for bioethanol production optimization. Energy for Sustainable Development, Biomass and Bioenergy 35:2006-2012.

Kathayat, R., A.S.Jaiswal, S.F., Basir, and S.K. Bansal, (1997). Dietary protein deficiency induced changes in protein kinase $\mathrm{C}$ activity and phospholipid metabolism in rat hepatocytes. Indian J. Exp. Biol. 
Katsuyama, M, Y. Kobayashi, H Ichikawa, A Mizuno, Y, Miyachi , K Matsunaga, and M .Kawashima (2005). A novel method to control the balance of skin microflora: Part 2. A study to assess the effect of a cream containing farnesyl and xylitol on atopic dry skin. J. Dermatol. Sci., 38: 207-213.

Kip, P., D. Meyer, and R.H. Jellema (2006). Inulins improve sensory and textural properties of low-fat yoghurts. Int Dairy J., 16:1098-1103.

Komatsu , T. R., Flávia C.A. Buriti, Roberta C. Da Silva, Alexandre R. Lobo, Célia Colli ,Luiz A. Gioielli, and Susana M.I. Saad, .(2013). Nutrition claims for functional guava mousses produced with milk fat substitution by inulin and/or whey protein concentrate based on heterogeneous food legislations. $L W T$ - Food Science and Technology 50:755-765.

Kubmarawa, D., I. A Ogunwande,. N. D. A Okorie,. O.Olawore, and A. A. Kasali (2005). Chemical constituents of the volatile oil of Cyperus esculentus L. from Nigeria Flavour and Fragrance Journal; 20: 640641.

Lankaputhra, W.E.V., and N.P Shah,. (1996). A simple method for selective enumeration of Lactobacillus acidophilus in yoghurt supplemented with L. acidophilus and Bifidobacterium spp.Milchwissenschaft 51,446-451.

10.1002/ffj.1517Lambert, R.J.W., P.N.Skandamis,; P.Coote,; and G.J.E. Nychas, (2001). A study of the minimum inhibitory concentration and mode of action of oregano essential oil, thymol and carvacrol. J. Appl. Microbiol. 91: 453-462.10.1046/j.1365-2672.2001.01428.x

Legault, J. and A.Pichette (2007). .Potentiating effect of $\beta$-caryophyllene on anticancer activity of $\alpha$-humulene, isocaryophyllene and paclitaxel journal of Pharmacy and Pharmacology. 59, (12):1643-1647.

Luo, X. M., H. J. Wei, and S. P. Yang, (1983). Inhibitory Effects of Molybdenum on Esophageal and Forestomach Carcinogenesis in Rats J. Nat. Can. Inst., 71 (1) 75.

Makras, L. G., and L.Van Acker De Vuyst (2005). Lactobacillus casei subsp. Casei 8700:2 degrades inulin-type fructans exhibiting different degrees of polymerization. Applied and Environmental Microbiology, 71: 65316537

Mano, E. Olsson, Leif B. Ülow, Stenstymne, Anders S. Carlsson Shaker M. Arafat, Ahmed M. Gaafar, Amany M. Basuny and Shereen L. Nassef .(2009). Chufa Tubers (Cyperuses L.): As a new source of food, World Applied Sciences Journal 7(2):151-156.

Masso-Welch, P.A., D.Zangani, D., C.Ip, C., M.M., Vaughan, M.M., S.F., Shoemaker, S.F., S.O., McGee, S.O., and M.M. Ip, M.M. (2004). Isomers of conjugated linoleic acid differ in their effects on angiogenesis and survival of mouse mammary adipose vasculature. J. Nutr. 134:299-307.

Mattila- Sandholm, T., P. R. Myllarienen, G.Crittenden, R.Mongesen, M.Fonden and A.Saarel (2002). Technological challenger for future probiotic foods. Int. Dairy J., 12:173-182.

Miller, E. L. (1967). Determination of the tryptophan content in feeding stuffs with particular reference to cereals. J. Sci. Food Agric., 18 (9):381-386. 
Muhammad, N., E. Bamishaiye, , O. Bamishaiye, , L. Usman, (2011). Physicochemical properties and fatty acid composition of Cyperus esculentus (Tigernut) tuber oil. Biores. Bull. 5:51-54

Oliveira, R.P.S., P.Patrizia, M. N.Oliveira, , A Converti. (2011). Effect of inulin as a prebiotic to improve growth and counts of a probiotic cocktail in fermented skim milk. LWT- Food Science and Technology 44:520-523.

Ozer, D., M. S., Akin, and B.Ozer, (2005). Effect of inulin and lactulose on survival of Lactobacillus acidophilus LA 5 and Bifidobacteriumbifidum BB-02 in acidophilusbifidus yoghurt. Food Science and Technology International, 11:19-24.

Paseephol, T., and F. Sherkat (2009). Probiotic stability of yoghurts containing Jerusalem artichoke inulin during refrigerated storage .Journal Of Functional Foods.1:311-318.

Pinheiro, R., Pergo, P., Converti, A., Nogueira, M. (2009). The effect of inulin as a prebiotic on the production of probiotic fiber-enriched fermented milk. International Journal of Dairy Technology, 62:195-203.

Reimer, R. A., and J. C. Russell, (2008). Glucose tolerance, lipids, and GLPsecretion in JCR: LA-cr Ratf Fed h High Protein Fiber Diet. Obesity, 16: 40-46.

Rumessen, J. J., S.Bod, , O. Hamberg, H Gudm and E.Yer, (1990). Fructans of Jerusalem artichokes: Intestinal transport, absorption, fermentation, and influence on blood glucose, insulin, and c-peptide responses in healthy subjects. American Journal of Clinical Nutrition, 52(4): 675-681.

Salwa M. El-Shebini, M.D.; I.A. Maha, M.D.Moaty,; Salwa T. Tapozada, M.D.; Laila M. Hanna, Ph.D.; Hamed I. Mohamed, Ph.D. M.Hala and M.D. Raslan, (2010). Effect of Regular Consumption of Tiger Nut (Cyperus esculentus) on insulin resistance and tumor necrosis factoralpha in obese type 2 diabetic Egyptian women. Med. J. Cairo Univ., 78, 2(12), 607-614.

Shah, N. P. (1995). Urvival of Lactobacillus acidophilus and Bifidobacterium in commercial yoghurt during refrigerated storage. International Dairy Journal, 5,515-521.

Shori, A.B., A.S Baba, (2011).Comparative antioxidant activity,proteolysis and in vitro $\alpha$-amylase and glucosidase inhibition of Allium sativumyogurts made from cow and camel milk, Journal of Saudi Chemical Society http://dx.doi.org/10.1016/j.jscs.2011.09.014.

Srisuvor, N.; C.Ninnart, , P.Cheunjit, and S.Suwanna (2013). Effect of inulin and polydextose on physicochemical and sensory properties of low fat set yoghurt with probiotic-cultured banana pure. LWT. Food Science and Technology. 51, 30-36.

Temple, V. J., T. O. Ojebe and M. M. Kapu (1989). Chemical analysis of tiger nut (Cyperus esculentus). J. Sci. Agric. 49:261-262.

Tamime, A. Y., M. Saarela, A. K.Søndergaard, , V. V. Mistry, and N. P. Shah, (2005). Production and maintenance of viability of probiotic microorganisms in dairy products. In A. Y. Tamime (Ed.), Probiotic dairy products (pp. 39-72). Oxford: Blackwell. 
Turhan, M., S. Sayarand, and S Gunasekaran,. (2002). Application of Peleg model to study water absorption in chickpea during soaking. Journal of Food Engineering, 53, 153-159.

Wang, J., C. M., Rosell, and C. Benedito de Barber, (2002). Effect of the addition of different fibers on wheat dough performance and bread quality. Food Chemistry, 79(2): 221-226.

WHO , (1985). WHO/FAO Report: Energy and Protein Requirements.WHO Technical Report Series No. 724. World Health Organization Geneva.

Yang, D, L. Michel, J.P. Chaumont and J..Millet-Clerc (1999).Use of caryophyllene oxide as an antifungal agent in an in vitro experimental model of onychomycosis. Mycopathologia, 148: 79-82.

Temple, V. J. , Ojebe T. O. and Kapu M. M. (1989)Chemical analysis of tiger nut (Cyperus esculentis). J. Sci. Agric. 49:261-262.Wang, J., Rosell, C. M., and Benedito de Barber, C. (2002)Effect of the addition of different fibers on wheat dough performance and bread quality. Food Chemistry, 79(2): 221-226.

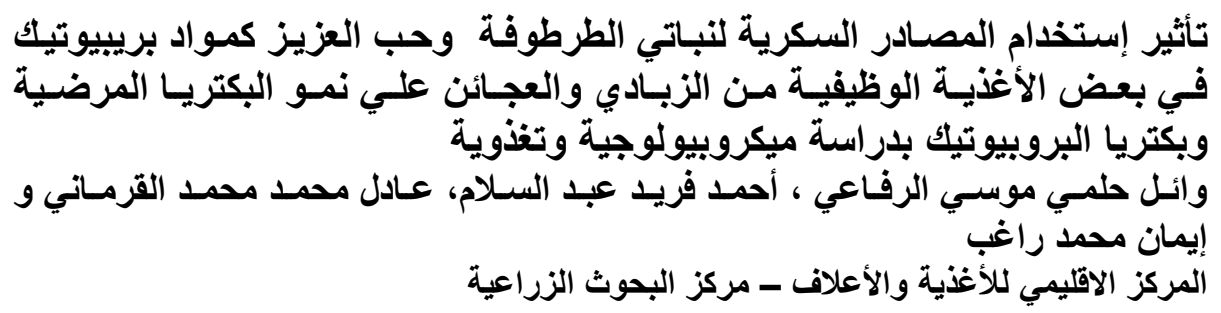

لتحسين إنتاج أغذية محتويـة علي البروبيوتيك تطرقت هذئة الدراسـة إلي امكانيـة إستخدام

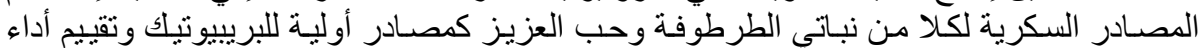

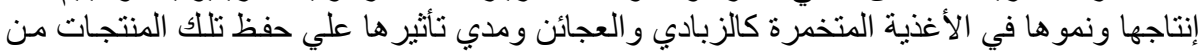

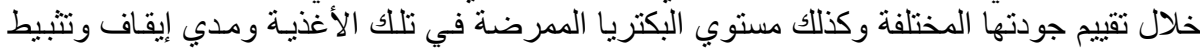

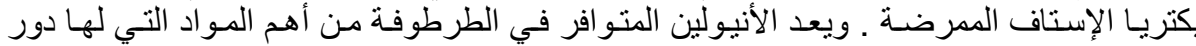

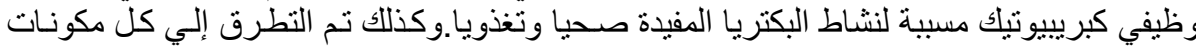

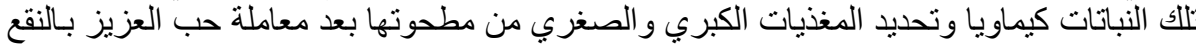
و التجفيف.

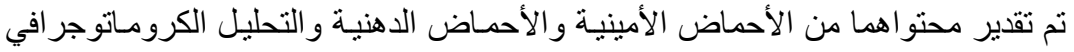

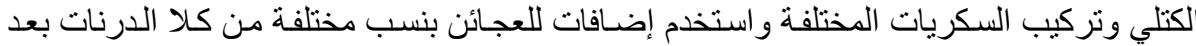

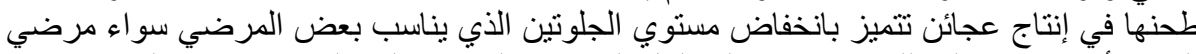

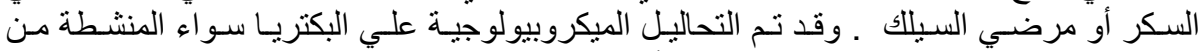

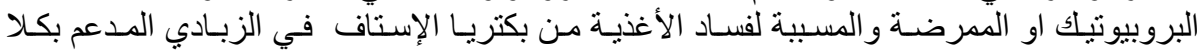

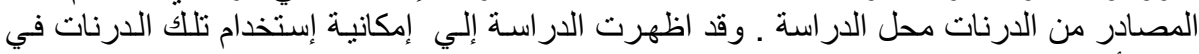

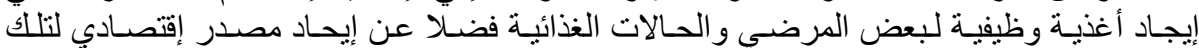

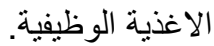

